\title{
HOW DOES PATENT LITIGATION INFLUENCE DYNAMIC RISK FOR MARKET COMPETITORS?
}

\author{
Yi-Hsien WANG ${ }^{\mathrm{a}}$, Wan-Rung LINª, Shu-Shian LIN ${ }^{\mathrm{b}}$, Jui-Cheng HUNG ${ }^{\mathrm{a}}$ \\ ${ }^{a}$ Department of Banking and Finance, Chinese Culture University, Taipei, Taiwan \\ ${ }^{b}$ Department of International Business Administration, Chinese Culture University, Taipei, Taiwan
}

Received 20 September 2013; accepted 03 November 2014

\begin{abstract}
Many recent studies have discussed the appropriateness of various patent measurement indicators, as well as the differences in the positioning of patented technologies, while there is little discussion on the risk transmission of enterprises when faced with infringement litigation. This study used the bivariate EGARCH (Exponential Generalized Autoregressive Conditional Heteroskedasticity) model with DCC (Dynamic Conditional Correlations) to investigate the dynamic risk transmission of patent litigation between market competitors in the smartphone industry. Empirical results revealed that when facing lawsuits from market challengers, the market leader faces fewer risks when handling patent infringement litigations. In addition, the risk reactions of competitors during patent wars may widely differ. Investors should consider the patent infringement litigations when measuring the dynamic risks of share prices, and determining the optimal configuration of asset portfolios in response.
\end{abstract}

Keywords: patent infringement, patent litigation, market competitor, EGARCH, dynamic risk.

JEL Classification: C32, K41, O32.

\section{Introduction}

In the current market, it is important for enterprises to define their industrial positions and markets, as well as analyze their competitive advantages and profit-making potentials. In order to maintain competitiveness, they need to actively develop their positions and strategies in patent $R \& D$, control key technologies, realize low costs, differentiate barrier strategies, and accumulate technological innovative niches through the accumulation of patents (Hall et al. 2005; Johanson et al. 2006).

In a highly competitive industry, patents are not only a key indicator of competitiveness, but also a powerful tool for increasing corporate revenue, carrying out transnational mergers and acquisitions, and driving new business in global competition. Currently, Taiwan's

Corresponding author Yi-Hsien Wang

E-mail: holland@mail2000.com.tw 
industrial structure is being restructured, thus domestic brands are striving to gain visibility. Consequently, patent litigation cases launched by internationally renowned manufacturers against Taiwanese businesses are becoming more common. Therefore, Taiwanese enterprises must develop key technology research and development $(\mathrm{R} \& \mathrm{D})$, actively improve patent quality, and establish patent teams in order to compete in international markets and confidently face international patent litigation (Griliches 1981; Narin et al. 1987; Trajtenberg 1990; Crampes, Langinier 2002; Hall et al. 2005; Arora et al. 2008; Coe et al. 2009).

Patents can protect a company's products and expand its competitive advantage; however, patent litigation has rapidly increased in recent years. In the past, enterprises earned profits by increasing production, lowering costs, and enhancing efficiency (Kaplan, Norton 2004; Koo, Kim 2009; Adams 2010); thus, business performance was largely associated with tangible assets. However, with the advent of the knowledge-based economy, business management has experienced a considerable revolution. The enterprise value and growth rely on intangible assets, of which patents form the core value of enterprises (Jaffe et al. 2000; Lev 2001).

This study aims to investigate the risk transmission of patent infringement litigation. The bivariate EGARCH (Exponential Generalized Autoregressive Conditional Heteroskedasticity) model is employed with a dynamic conditional correlation. The stock return volatility is used to measure the impact of patent infringement litigation, and the dynamic risk transmission of patent litigation within market competitors is discussed. The findings can serve as a reference for enterprises on related decisions. The remainder of this paper is organized as follows. Section 1 is the literature review; Section 2 describes the sample data and the dynamic condition bivariate asymmetric GARCH model; Section 3 presents the empirical results; the last Section offers conclusions.

\section{Literature review}

$\mathrm{R} \& \mathrm{D}$ is closely correlated with the competitiveness of an enterprise (Hall, Ziedonis 2001; Trajtenberg 2001; Lee et al. 2013). Oughton et al. (2002) and Bessen (2008) studied industrial characteristics and R\&D activities. Lakdawalla and Sood (2009) discussed the characteristics of the electronics, biology, pharmaceutical, telecommunications and manufacturing industries, as well as the differences in innovation capabilities of those industries (Lakdawalla, Sood 2009; Cooke 2002; Tseng, Wu 2007).

Jensen and Webster (2006) used patent data to study the relationship between firm size and patent intensities in Australia. Bessen and Maskin (2009) and Geradin et al. (2011) found that the number of patents is highly correlated with firm size, and larger companies tend to treat patents as a competitive niche (Kim et al. 2008; Blind et al. 2009; Trippl, Maier 2010).

In the current market, patents play a pivotal role in $\mathrm{R} \& \mathrm{D}$ as a measurable indicator. Therefore, most studies have discussed the relationship between resource investment and patent output (Lanjouw, Schankerman 2004; Agliardi, E., Agliardi, R. 2011). Megna and Klock (1993), Ernst et al. (2010), and Suzuki (2011) measured patent indicators and business performance. Other studies have discussed various $\mathrm{R} \& \mathrm{D}$ input indicators, including 
R\&D expenditure ( $R \& D$ intensity or technological overflow), R\&D technology sources (self-innovation, introduction for modification, partial introduction, total introduction and returns of royalty) and $\mathrm{R} \& \mathrm{D}$ output (number of patents and the number of new products to the market) (Thomas 2001; Watanabe et al. 2001; Hall, Bagchi-Sen 2002; Schoenecker, Swanson 2002; Reitzig 2003; Tseng, Wu 2007).

Patents are effective tools for increasing profits and maintaining market competitiveness. With the continuous accumulation of R\&D strength, enterprises can use patents to generate substantial profits (Bukh 2003; Bebchuk, Cohen 2005). Lee et al. (2013) studied industrial competitiveness in relation to patents, and found that commercializing patents are an important topic of research. Patent rights, such as trademark rights, copyrights, or other intellectual property rights, are intellectual capitals, and have a significant impact on business. These findings agree with those of Johanson et al. (2001) and Arcelus et al. (2005).

Most relevant studies have focused on $R \& D$ indicators and $R \& D$ expenditures, while the impact of long and tedious patent litigation on the market has seldom been discussed. In recent years, Raghu et al. (2008) and Lee et al. (2013) found that patent infringement cases have grown in number. Lacking effective review of patent layout effectiveness, some enterprises are rather disadvantaged in patent defense and attacks regarding patent layout. As a result, intellectual properties cannot be fully used. Moreover, some enterprises use litigation in business competition, leading to a long patent infringement litigation process. If an enterprise is defeated in litigation, it has to pay a large amount in royalties, franchise fees, or damages, but may also be forced out of the market. The resources allocation of enterprises is closely related to market information efficiency. It not only affects the company value in the market economy, but also reflects the confidence of market investors and investment trends. Therefore, understanding the dynamic risk structure of patent infringement litigation is an important issue for the government, academia and industry (Bhagat et al. 1994; Lerner 1994; Fisher, Statman 2000).

\section{Sample and methodology}

\subsection{Data selection and description}

Since the 80s, the IT industry has become the backbone of Taiwan's economic growth. The IT industry, which produces personal computers, notebook computers, panel screens, consumer electronic products, etc., plays a pivotal role in the high-tech industry supply chain. The launch of iPhone by Apple in 2007 triggered a boom and soaring demand for smart phones, and created a new development direction of consumer electronic products, thus reforming the supply chain system. Due to the positive user experience of iPhone, Google also entered the smartphone market by launching the Android platform in cooperation with the Open Handset Alliance, and using open source to create innovations in the smartphone industry (Chen et al. 2013).

In a highly competitive market, well-known smartphone makers have created great value from the design, manufacturing, and system integration processes of smartphones (Li, Whalley 2002). However, the volume licensing of the open Android operating system is 
dominated by Google. Google's rapid increase the market share and competitiveness in the global smartphone market has put considerable pressure on the Apple iPhone. Therefore, Apple started a patent litigation war in 2010, and charged HTC with infringement on 20 patents on March 2, 2010. The litigation wars were waged in the United States, the United Kingdom and Germany, and covered the range from smartphones to tablet computers. It escalated from patent infringement to the ruling of a permanent ban by the U.S. government. HTC-made mobile phones were banned from entering the U.S. After this patent lawsuit, HTC immediately launched a counter lawsuit against Apple. On May 12, 2010, HTC charged Apple, and initiated five claims of patent infringement litigation. HTC also petitioned to the International Trade Commission (ICT) against sanctions, including the ban on sales of disputed products in the U.S. These actions/reactions have made the smartphone industry highly competitively (Chen et al. 2013).

This study aims to discuss the escalating patent wars between Apple (market leader) and HTC (market challenger) over the period between 2010 and $2012^{1}$, from the viewpoint of industrial competitiveness (Porter 1980, 2008; Chen, MacMillan 1992; Chen, Hambrick 1995; Chen 1996). The data included 18 patent infringement cases filed by Apple (includes Apple Inc., NeXT Software and NeXT Computer) and HTC $^{2}$ (includes HTC Corp, HTC America Inc., and HTC unit Exedea Inc.). Patent infringement data from 2010 to 2012 were collected from the UDN database. The announcement date for each patent infringement event was verified by the Market Observation Post System (MOPS) of the Taiwan Stock Exchange (TWSE). In addition, the authenticity of the samples and the classification of the samples into plaintiff, defendant and litigation event were reviewed to ensure the comprehensiveness and completeness of the research samples. The patent infringement data met the following criteria: (1) certain words and their synonyms (such as "patent", "infringement", "litigation", "defendant", "plaintiff" and "ruling") were used to describe the news about the Apple and HTC as they sued each other for patent infringement; these words were searched as keywords in the UDN database; (2) there were no other patent infringement events within five days before or after the announcement date; this was to avoid potentially confusing patent infringement events that could confuse the effects of the patent infringement (Lai et al. 2010); (3) the daily stock prices of Apple and HTC were available from Yahoo Finance and the Taiwan Economic Journal (TEJ) database, respectively.

\footnotetext{
1 Apple and HTC started patent litigation war in 2010, and have reached a global settlement on November 10, 2012 that includes the dismissal of all current lawsuits and a ten-year license agreement. The license extends to current and future patents held by both parties (Apple Press Info: http://www.apple.com/pr/library/2012/11/11HTC-andApple-Settle-Patent-Dispute.html).

${ }^{2}$ HTC was founded in 1997 and specialized in OEM business in early times. Later, the company built its own brand. In 2002, HTC produced the world's first smartphone, the Microsoft Smartphone 2002. At that time, it had an $80 \%$ market share of the Windows smartphone. In June 2006, HTC launch smartphones under its own brand. HTC grew rapidly in 2011 and ranked $98^{\text {th }}$ in the world brand value list of Best Global Brands, and had a 15\& global market share in the Android operating system market (Android operating systems accounted for $42 \%$ of the market share in 2011), becoming one of the world's leading smartphone manufacturers.
} 


\subsection{Methodology design: perspective of dynamic risk}

ARCH (Autoregressive Conditional Heteroskedasticity) and GARCH (Generalized Autoregressive Conditional Heteroskedasticity) models have been used to estimate the timevarying volatility of the financial market (Engle 1982; Bollerslev 1986). They use an asymmetric model to capture asymmetric volatility (Nelson 1991; Glosten et al. 1992; Hentschel 1995; Deb 1996). Recent studies have used the multivariate GARCH model with DCC specification to estimate systematic patterns on co-movement (Kroner, Ng 1998; McAleer et al. 2009; Chuang et al. 2014), as well as the DCC-EGARCH (Dynamic Conditional Correlations-Exponential GARCH) model to capture the volatility transmission of financial data in the estimation process (Kawakatsu 2006; Wang, Moore 2008; Asai, McAleer 2011).

To estimate the dynamic risk relationship, this paper uses a bivariate EGARCH model with DCC specification to capture the risk transmission of patent infringement between Apple and HTC stock returns (Engle 2002; Wang, Moore 2008). The model settings are shown as follows:

$$
R_{k, t}=\alpha_{k, 0}+\tau\left(\ln P_{1, t-1}-\kappa-\delta \ln P_{2, t-1}\right)+\sum_{i=1}^{3} \alpha_{k, i} P L_{i}+\sum_{j=1}^{2} \beta_{k, j} R_{t-1}+\varepsilon_{k, t},
$$

where $R$ is the $2 \times 1$ vector of stock returns, and $\alpha_{k, 0}$ is the $n \times 1$ Intercept Vector. $\beta_{k, j}$ is the $2 \times 2$ vector from which the effect of mean transmission across the companies is captured by the off-diagonal elements. Where $R_{k, t}=\ln P_{k, t}-\ln P_{k, t-1}$ and $\ln P_{k, t}$ is the natural logarithm of the price of company $k$ in period $t$, the conditional mean equations can be written as Equation (1), and $R_{1, t}$ and $R_{2, t}$ denote Apple and HTC stock returns in period $t$, respectively; $\ln P_{1, t-1}=\kappa-\delta \ln P_{2, t-1}$ represents the long term equilibrium relationship between the Apple and HTC stock returns; $\tau\left(\ln P_{1, t-1}-\kappa-\delta \ln P_{2, t-1}\right)$ are the error modification terms; $P L_{i}$ denotes the dummy of patent litigation, when $P L_{1}$ equals 1 , it means that HTC filed a patent infringement suit against Apple, otherwise it equals 0. $P L_{2}$ represents Apple filing a lawsuit against HTC for infringing on Apple-related patents $\left(P L_{2}=1\right) ; \mathrm{PL}_{3}$ are from the patent war series between HTC and Apple $\left(P L_{3}=1\right)$. In addition, $\varepsilon_{k, t}$ is assumed to be $\varepsilon_{k, t} \mid \Omega_{t-1} \sim N\left(0, H_{t}\right)$ and the conditional covariance matrix is $H_{t}$ :

$$
H_{t}=H_{t} W_{t} D_{t}
$$

where $W_{t}$ is a $2 \times 2$ diagonal matrix composed of the time-varying standard deviations obtained from the EGARCH model on the diagonal, and $W_{t}$ is the time-varying nature of the symmetric conditional correlation matrix. Thus, the conditional variances for each company can be modeled as exponential functions of past standardized innovations (Nelson 1991; Engle 2002; Kawakatsu 2006; Wang, Moore 2008) and expressed as:

$$
\begin{gathered}
h_{k, t}=\exp \left\{\omega_{k, 0}+\sum_{i=1}^{3} \omega_{k, i} P L_{i}+\sum_{j=1}^{n} g_{k, j}\left(u_{j, t-1}\right)+\theta_{k} \ln h_{k, t-1}\right\} ; \\
g_{j}\left(u_{j, t-1}\right)=\left|u_{j, t-1}\right|-E\left(u_{j, t-1}\right)+\varphi_{j} u_{j, t-1},
\end{gathered}
$$

where the conditional variance $u_{j, t-1}=\varepsilon_{j, t-1} / \sigma_{j, t-1}$ in each company is in Equation (2), 
and the volatility persistence is captured by $\theta_{i}$, which satisfies the finite unconditional variance if $\theta_{k}<1$. The volatility spillovers are estimated by $\zeta_{k, j}(j \neq k)$, and the asymmetry exhibits the negative sign of $\varphi_{j}$ (Nelson 1991; Wang, Moore 2008).

\section{Empirical result}

\subsection{Basic statistics of Apple and HTC}

The results showed that the patent infringement events have significantly influenced stock market behavior. As some studies only discuss the temporal behavior of the stock market while ignoring the stock shocks of patent infringement, this paper presents a preliminary analysis of the Apple and HTC stock price. Trends for the daily Apple and HTC stock price indexes are shown in Figure 1, and the trends of both stocks' returns are shown in Figure 2. Figure 1 shows that from 2010 to 2012, the share price of Apple increased sharply, while the share price of HTC declined from its peak in 2011 to the original level. As shown in Figure 2, from 2010 to 2012, the change in returns on the share price of Apple was relatively stable, while that of HTC was relatively dramatic. Table 1 presents the symbols for the daily Apple and HTC stock price indexes during the sample period. The basic statistics present the stock mean returns, standard deviations, skewness, excess kurtosis, minimum and maximum returns and the Jarque-Bera test statistics.
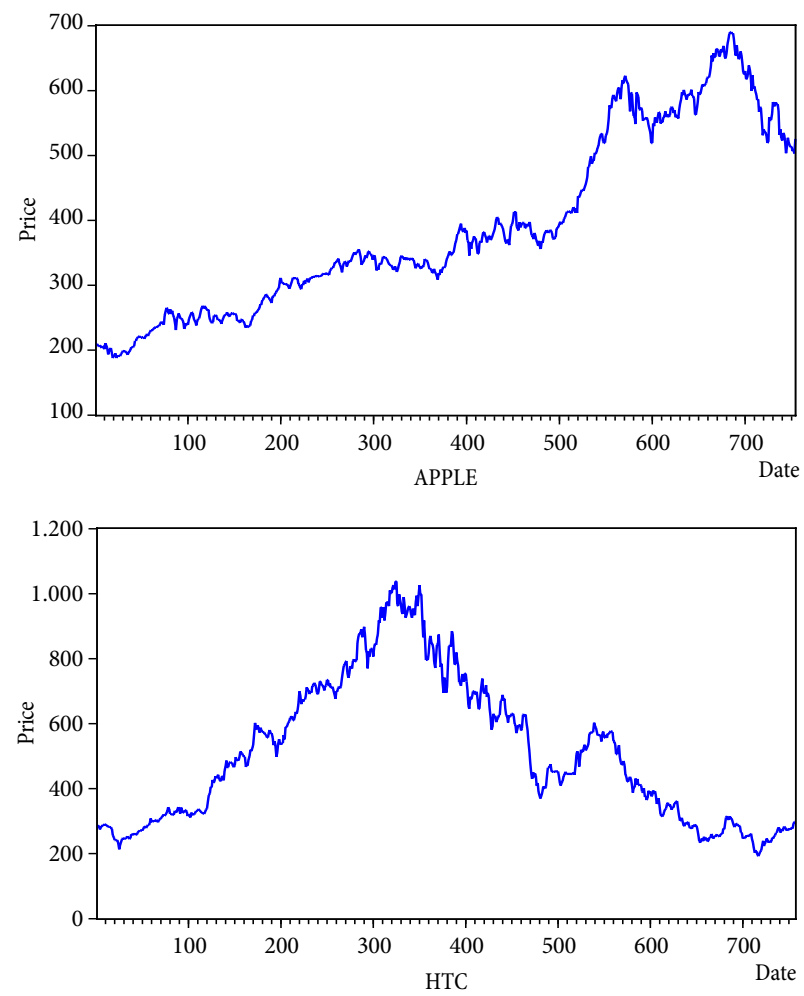

Fig. 1. The trend graph of Apple \& HTC stock prices 

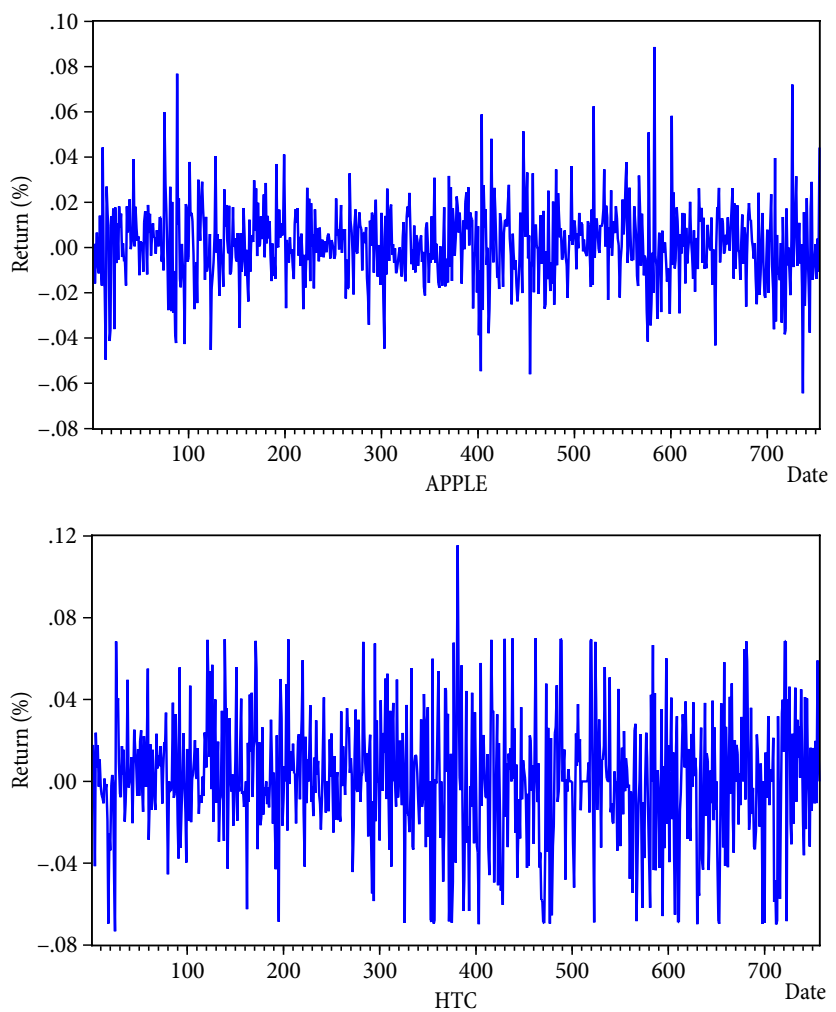

Fig. 2. The trend graph of Apple \& HTC stock returns

Table 1. Basic statistics for Apple \& HTC stock returns

\begin{tabular}{ccc}
\hline Statistics & APPLE & HTC \\
\hline Mean & 0.0014 & 0.0005 \\
\hline Std. Dev. & 0.0173 & 0.0306 \\
\hline Maximum & 0.0887 & 0.1154 \\
\hline Minimum & -0.0644 & -0.0733 \\
\hline Skewness & 0.2789 & -0.0535 \\
\hline Kurtosis & 5.3443 & 3.2528 \\
\hline J-B & $182.1822^{* *}$ & $2.3740^{* *}$
\end{tabular}

Notes: ${ }^{* \star}\left({ }^{\star}\right)$ denotes statistical significance at $1 \%(5 \%)$ level. Normal test is checked by the Jarque-Bera test and are asymptotically chi-square distributed with 2 degree of freedom.

The statistics of the sample are shown in Table 1. The means of Apple and HTC stock returns significantly differ from 0 at the $5 \%$ level. As seen, the skewness of Apple returns and HTC returns is respectively positive and negative. The positive and negative skewness indicates that the distribution of Apple and HTC stock returns has the heavier tail and the higher probability of gaining positive and negative returns respectively. In addition, both kurtosis statistics are over 3 , suggesting that the distribution of stock returns has leptokurtosis, and deviates from normality. Finally, the Jarque-Bera statistics for the Apple and HTC stock returns series significantly reject the assumption of normality. 


\subsection{Dynamic Risk relationship of patent litigation}

Section 3.2 shows the dynamic risk relationship of patent infringement between Apple and HTC. In Table 2, the empirical evidence suggests that when sued by HTC (market challenger) for patent infringement, Apple (market leader) saw the risks to its stock returns significantly reduced. In other words, the patent lawsuits brought by HTC cannot effectively threaten Apple. This paper infers that HTC, given its origin as an OEM, does not yet have a sufficient number of patents to deter or discourage Apple from using the relevant patents or selling restricted products. In summary, Apple's risk in undertaking patent infringement was significantly reduced $\left(\omega_{1,1}\right)$; however, HTC saw no noticeable reduction in patent risks $\left(\omega_{2,1}\right)$.

Meanwhile, when HTC was sued by Apple for patent infringements, HTC's stock returns $\left(\alpha_{2,2}\right)$ were significantly and negatively affected. During the lawsuit, Apple sought to restrict HTC from selling in the U.S. or selling smartphones with shorter lifecycles in certain markets by requesting preliminary injunctions or provisional measures. These approaches were aimed at slowing the sales growth of HTC's new products. In fact, patents were rather ineffective in the smartphone market due to the large number of relevant patents and the acceleration of product development. As a result, a decision over patent infringements may stifle competitors for a few months but cannot lock them out of the market, which is the reason that HTC and other Android players have been increasing acquisitions in order to obtain key patents. They have also been circumventing patents by designing around them, thus undermining the product advantages of Apple. In the face of lawsuits from Apple regarding patent infringements, neither Apple nor HTC experienced any significant impact on risks $\left(\omega_{1,2}, \omega_{2,2}\right)$.

Since 2010, Apple has been taking the initiative in patent-related litigations; however, HTC has fought back by suing Apple. Both companies have emphasized the importance of preventing patent infringement. However, the legal actions taken by Apple against HTC are testimony to HTC's R\&D results. In addition, HTC is supported by operating system vendors such as Google and Microsoft. Investors may interpret patent lawsuits as having a certain degree of impact on Apple, which is the reason that the risks associated with the infringement of Apple's patents are significantly higher $\left(\omega_{1,3}\right)$, while the similar risks HTC undertakes are significantly lower $\left(\omega_{2,3}\right)$. The acquisition of patents will be a major battlefield for companies competing in the global market. In fact, winning a patent war means more than grabbing market share. If tech manufacturers in Taiwan continue on the hardware and OEM path, they will eventually pay a huge and incalculable price for patent costs. This will be the biggest risk to their future profitability and may turn their wafer-thin profits into losses. Investors should also pay attention to the patent strategies and $\mathrm{R} \& \mathrm{D}$ strengths of individual companies, as these factors will be priced into the risks and returns of share prices (Chen et al. 2007; Tsai et al. 2011). 
Table 2. Dynamic risk of patent infringement within market competitors

\begin{tabular}{|c|c|c|c|}
\hline \multicolumn{2}{|c|}{ APPLE (market leader) } & \multicolumn{2}{|c|}{ HTC (market challenger) } \\
\hline Variable & Coefficient & Variable & Coefficient \\
\hline \multicolumn{4}{|c|}{ Conditional Mean Equation } \\
\hline$\alpha_{1}$ & $\begin{array}{c}0.0615 \\
(0.0571)\end{array}$ & $\alpha_{2}$ & $\begin{array}{c}0.0204 \\
(0.1022)\end{array}$ \\
\hline$\alpha_{1,1}$ & $\begin{array}{l}-0.1159 \\
(0.5708)\end{array}$ & $\alpha_{2,1}$ & $\begin{array}{c}0.9807 \\
(0.8675)\end{array}$ \\
\hline$\alpha_{1,2}$ & $\begin{array}{c}0.0816 \\
(1.1717)\end{array}$ & $\alpha_{2,2}$ & $\begin{array}{c}-1.8004^{* *} \\
(0.9145)\end{array}$ \\
\hline$\alpha_{1,3}$ & $\begin{array}{c}0.0358 \\
(0.5668)\end{array}$ & $\alpha_{2,3}$ & $\begin{array}{c}0.2115 \\
(0.5927)\end{array}$ \\
\hline$\tau_{1}$ & $\begin{array}{l}-0.3215^{*} \\
(0.1644)\end{array}$ & $\tau_{2}$ & $\begin{array}{l}-0.5939^{*} \\
(0.3238)\end{array}$ \\
\hline$\beta_{1,1}$ & $\begin{array}{c}0.0351 \\
(0.0414)\end{array}$ & $\beta_{2,1}$ & $\begin{array}{l}0.1437^{* * *} \\
(0.0604)\end{array}$ \\
\hline$\beta_{1,2}$ & $\begin{array}{c}0.0324 \\
(0.0226)\end{array}$ & $\beta_{2,2}$ & $\begin{array}{l}0.0649^{*} \\
(0.0405)\end{array}$ \\
\hline \multicolumn{4}{|c|}{ Conditional Variance Equation } \\
\hline$\omega_{1,0}$ & $\begin{array}{c}-0.2537^{* * \star} \\
(0.0606)\end{array}$ & $\omega_{2,0}$ & $\begin{array}{c}0.2790 \\
(0.4367)\end{array}$ \\
\hline$\omega_{1,1}$ & $\begin{array}{c}-4.0913^{* * \star} \\
(0.0678)\end{array}$ & $\omega_{2,1}$ & $\begin{array}{c}-0.1951 \\
(0.7702)\end{array}$ \\
\hline$\omega_{1,2}$ & $\begin{array}{c}0.8630 \\
(1.6623)\end{array}$ & $\omega_{2,2}$ & $\begin{array}{l}-0.2619 \\
(1.9588)\end{array}$ \\
\hline$\omega_{1,3}$ & $\begin{array}{l}2.4843^{* * *} \\
(0.0665)\end{array}$ & $\omega_{2,3}$ & $\begin{array}{c}-2.4313^{* * *} \\
(0.7675)\end{array}$ \\
\hline$\theta_{1,1}$ & $\begin{array}{l}0.9614^{* * *} \\
(0.0176)\end{array}$ & $\theta_{2,1}$ & $\begin{array}{c}0.2943^{* * *} \\
(0.0809)\end{array}$ \\
\hline$\zeta_{1,1}$ & $\begin{array}{l}0.5830^{* * *} \\
(0.1311)\end{array}$ & $\zeta_{2,1}$ & $\begin{array}{c}0.0946 \\
(0.3149)\end{array}$ \\
\hline$\varphi_{1,1}$ & $\begin{array}{l}1.0818^{* * *} \\
(0.2123)\end{array}$ & $\varphi_{2,1}$ & $\begin{array}{l}-0.0047 \\
(0.5633)\end{array}$ \\
\hline$\theta_{1,2}$ & $\begin{array}{c}-0.0397^{* * *} \\
(0.0017)\end{array}$ & $\theta_{2,2}$ & $\begin{array}{l}0.7557^{* * *} \\
(0.0400)\end{array}$ \\
\hline$\zeta_{1,2}$ & $\begin{array}{l}2.0492^{* * *} \\
(0.4180)\end{array}$ & $\zeta_{2,2}$ & $\begin{array}{l}3.9026^{* * *} \\
(1.3949)\end{array}$ \\
\hline$\varphi_{1,2}$ & $\begin{array}{c}0.2944 \\
(0.3998)\end{array}$ & $\varphi_{2,2}$ & $\begin{array}{l}8.0328^{* *} \\
(2.4989)\end{array}$ \\
\hline \multicolumn{4}{|c|}{ Dynamic Conditional Correlation } \\
\hline$\varpi_{0}$ & $\begin{array}{c}-2.9517^{* * *} \\
(0.3734)\end{array}$ & $\varpi_{1}$ & $\begin{array}{l}5.4493^{* * *} \\
(1.7693)\end{array}$ \\
\hline$\varpi_{2}$ & $\begin{array}{l}-0.5084^{*} \\
(0.2754)\end{array}$ & & \\
\hline
\end{tabular}

Note: ${ }^{*}{ }^{* *}$ and ${ }^{* * *}$ is significant at the $0.1,0.05$ and 0.01 level. 


\section{Conclusions}

This study found that Apple's risks in undertaking patent infringement are significantly reduced when Apple is sued by HTC for patent infringement. Moreover, during patent wars, the patent risks for both companies are significantly different. Due to accelerated industrial upgrading and increasingly blurred boundaries between products in the smartphone industry, the probability of patent infringement litigation in the industrial structure has increased.

Currently, the global economic outlook is generally pessimistic. Manufacturers strive to win global market share in the competition for limited business growth opportunities. In the technology industry of Taiwan, besides the impact of delayed economic upturn, the strategic IP war waged by competitors to win market shares has also become a vital key to the future development of the business. With the patent litigation of HTC and Apple as examples, and the concerns of investment institutions about business growth, patent litigation has had a serious impact on the reshuffling of the global smartphone industry. Market players not only judge and make decisions based on the overall economic situation, information regarding $\mathrm{R} \& \mathrm{D}$ investment and the long legal processes of the investment targets should measure the overall risk of the industrial chain, in order to reduce investment risks through industrial layout and determine the optimal configuration of asset portfolios in response (Boldrin, Levine 2013; Lee et al. 2013).

\section{Aknowledgements}

We would like to thank the anonymous referees for helpful comments and suggestions, and Yi-Hsien Wang also would like to thank the Ministry of Science and Technology of Taiwan for financially supporting this research under Contract No. MOST 103-2410-H034-023-MY2.

\section{References}

Adams, S. R. 2010. The centenary patent - single-sleeve valve engines, World Patent Information 32(4): 320-325. http://dx.doi.org/10.1016/j.wpi.2010.05.005

Agliardi, E.; Agliardi, R. 2011. An application of fuzzy methods to evaluate a patent under the chance oflitigation, Expert Systems with Applications 38: 13143-13148. http://dx.doi.org/10.1016/j.eswa.2011.04.122

Arcelus, F. J.; Mitra, D.; Srinivasan, G. 2005. On the incidence of deferred taxes, intangibles and nonlinearities in the relationship between Tobin's Q and ROI, Journal of Economics and Business 57(2): 165-185. http://dx.doi.org/10.1016/j.jeconbus.2004.09.003

Arora, A.; Ceccagnolib, M.; Cohenc, W. 2008. R\&D and the patent premium, International Journal of Industrial Organization 26(5): 1153-1179. http://dx.doi.org/10.1016/j.ijindorg.2007.11.004

Asai, M.; McAleer, M. 2011. Dynamic conditional correlations for asymmetric processes, Journal of Japan Statistical Society 41(2): 143-157. http://dx.doi.org/10.14490/jjss.41.143

Bebchuk, L. A.; Cohen, A. 2005.The costs of entrenched boards, Journal of Financial Economics 78: 409-433. http://dx.doi.org/10.1016/j.jineco.2004.12.006

Bessen, J. 2008. The value of U.S. patents by owner and patent characteristics, Research Policy 37(5): 932-945. 
Bessen, J.; Maskin, E. 2009. Sequential innovation, patents, and imitation, RAND Journal of Economics 40(4): 611-635. http://dx.doi.org/10.1111/j.1756-2171.2009.00081.x

Bhagat, S.; Brickley, J. A.; Coles, J. L. 1994. The costs of inefficient bargaining and financial distress: evidence from corporate lawsuits, Journal of Financial Economics 2(2): 221-247. http://dx.doi.org/10.1016/0304-405X(94)90005-1

Blind, K.; Cremers, K.; Mueller, E. 2009. The influence of strategic patenting on companies' patent portfolios, Research Policy 38(2): 428-436. http://dx.doi.org/10.1016/j.respol.2008.12.003

Boldrin, M.; Levine, D. K. 2013. The case against patents, Journal of Economic Perspectives 27(1): 3-22. http://dx.doi.org/10.1257/jep.27.1.3

Bollerslev, T. 1986. Generalized autoregressive conditional heteroskedasticity, Journal of Econometrics 31: 307-327. http://dx.doi.org/10.1016/0304-4076(86)90063-1

Bukh, P. N. 2003. Commentary the relevance of intellectual capital disclosure: a paradox?, Accounting, Auditing and Accountability Journal 16(1): 49-56. http://dx.doi.org/10.1108/09513570310464273

Chen, M. J. 1996. Competitor analysis and interfirm rivalry: toward a theoretical integration, Academy of Management Review 21(1): 100-134.

Chen, M. J.; MacMillan, I. G. 1992. Nonresponse and delayed response to competitive moves: the roles of competitor dependence and action irreversibility, Academy of Management Journal 35(3): 539-570. http://dx.doi.org/10.2307/256486

Chen, M. J.; Hambrick, D. C. 1995. Speed, stealth, and selective attack: how small firms differ from large firms in competitive behavior, Academy of Management Journal 38(2): 453-482. http://dx.doi.org/10.2307/256688

Chen, M. J.; Su, K. H.; Tsai, W. P. 2007. Competitive tension: the awareness, motivation, capability perspective, Academy of Management Journal 50(1): 101-118. http://dx.doi.org/10.5465/AMJ.2007.24162081

Chen, Y. M.; Yang, D. H.; Lin, F. J. 2013. Does technological diversification matter to firm performance? The moderating role of organizational slack, Journal of Business Research 66(10): 1970-1975. http://dx.doi.org/10.1016/j.jbusres.2013.02.020

Chuang, C. C.; Wang, Y. H.; Yeh, T. J.; Chuang, S. L. 2014. Backtesting VaR in consideration of the higher moments of the distribution for minimum-variance hedging portfolios, Economic Modelling 42: 15-19. http://dx.doi.org/10.1016/j.econmod.2014.05.037

Coe, D. T.; Helpman, E.; Hoffmaister, A. W. 2009. International R\&D spillovers and institutions, European Economic Review 53(7): 723-741. http://dx.doi.org/10.1016/j.euroecorev.2009.02.005

Cooke, P. 2002. Regional innovation systems: general findings and some new evidence from biotechnology clusters, Journal of Technology Transfer 27(1): 133-145. http://dx.doi.org/10.1023/A:1013160923450

Crampes, C.; Langinier, C. 2002. Litigation and settlement in patent infringement cases, RAND Journal of Economics 33(2): 258-274. http://dx.doi.org/10.2307/3087433

Deb, P. 1996. Finite sample properties of maximum likelihood and quasi-maximum likelihood estimators of EGARCH models, Econometric Reviews 15(1): 51-68. http://dx.doi.org/10.1080/07474939608800338

Engle, R. F. 1982. Autoregressive conditional heteroskedasticity with estimates of the variance of United Kingdom inflation, Econometrica 50: 987-1007. http://dx.doi.org/10.2307/1912773

Engle, R. F. 2002. Dynamic conditional correlation: a simple class of multivariate generalized autoregressive conditional heteroskedasticity models, Journal of Business and Econometrica Statistics 20(3): 339-350. http://dx.doi.org/10.1198/073500102288618487

Ernst, H.; Legler, S.; Lichtenthaler, U. 2010. Determinants of patent value: insights from a simulation analysis, Technological Forecasting and Social Change 77: 1-19.

http://dx.doi.org/10.1016/j.techfore.2009.06.009 
Fisher, K. L.; Statman, M. 2000. Investor sentiment and stock returns, Financial Analysts Journal 56(2): 16-23. http://dx.doi.org/10.2469/faj.v56.n2.2340

Geradin, D.; Layne-Farrar, A.; Padilla, A. J. 2011. Elves or trolls? The role of non-practicing patent owners in the innovation economy, Industrial and Corporate Change 20(3): 1-22.

Glosten, L.; Jagannathan, R.; Runkle, D. 1992. On the relation between the expected value and volatility of nominal excess returns on stocks, Journal of Finance 46: 1779-1801.

Griliches, Z. 1981. Market value, R\&D, and patents, Economics Letters 7(2): 183-187. http://dx.doi.org/10.1016/0165-1765(87)90114-5

Hall, L. A.; Bagchi-Sen, S. 2002. A study of R\&D intensity, innovation and business performance in the Canadian biotechnology industry, Technovation 22(4): 231-244. http://dx.doi.org/10.1016/S0166-4972(01)00016-5

Hall, B. H.; Jaffe, A.; Trajtenberg, M. 2005. Market value and patent citations, RAND Journal of Economics 36(1): 16-38.

Hall, B. H.; Ziedonis, R. H. 2001. The patent paradox revisited: an empirical study of patenting in the U.S. semiconductor industry, 1979-1995, RAND Journal of Economics 32(1): 101-128. http://dx.doi.org/10.2307/2696400

Hentschel, L. 1995. All in the family nesting symmetric and asymmetric GARCH models, Journal of Financial Economics 39(1): 71-104. http://dx.doi.org/10.1016/0304-405X(94)00821-H

Jaffe, A.; Trajtenberg, M.; Fogarty, M. 2000. Knowledge spillovers and patent citations: evidence from a survey of inventors, American Economic Review 90(2): 215-218.

http://dx.doi.org/10.1257/aer.90.2.215

Jensen, P. H.; Webster, E. 2006. Firm size and use of intellectual property rights, Economic Record 82(256): 44-55. http://dx.doi.org/10.1111/j.1475-4932.2006.00292.x

Johanson, U.; Koga, C.; Skoog, M.; Henningsson, J. 2006. The Japanese government's intellectual capital reporting guideline: what are the challenges for firms and capital market agents? Journal of Intellectual Capital 7(4): 474-491. http://dx.doi.org/10.1108/14691930610709121

Johanson, U.; Martensson, M.; Skoog, M. 2001. Measuring to understand intangible performance drivers, European Accounting Review 10(3): 407-437. http://dx.doi.org/10.1080/09638180126791

Kaplan, R. S.; Norton, D. P. 2004. Strategy maps: converting intangible assets into tangible outcomes. MA: Harvard Business School Press.

Kawakatsu, H. 2006. Matrix exponential GARCH, Journal of Econometrics 134(1): 95-128. http://dx.doi.org/10.1016/j.jeconom.2005.06.023

Kim, Y. G.; Suh, J. H.; Park, S. C. 2008. Visualization of patent analysis for emerging technology, Expert Systems with Applications 34(3): 1804-1812. http://dx.doi.org/10.1016/j.eswa.2007.01.033

Koo, J.; Kim, T. E. 2009. When R\&D matters for regional growth: a tripod approach, Regional Science 88(4): 825-840. http://dx.doi.org/10.1111/j.1435-5957.2009.00261.x

Kroner, K. E.; Ng, V. K. 1998. Modeling asymmetric comovements of asset returns, Review of Financial Studies 11(4): 817-844. http://dx.doi.org/10.1093/rfs/11.4.817

Lai, J. H.; Chang, S. C.; Chen, S. S. 2010. Is experience valuable in international strategic alliances?, Journal of International Management 16(3): 247-261. http://dx.doi.org/10.1016/j.intman.2010.06.004

Lakdawalla, D.; Sood, N. 2009. Innovation and the welfare effects of public drug insurance, Journal of Public Economics 93(3-4): 541-548. http://dx.doi.org/10.1016/j.jpubeco.2008.11.003

Lanjouw, J. O.; Schankerman, M. 2004. Patent quality and research productivity: measuring innovation with multiple indicators, Economic Journal 114: 441-465.

http://dx.doi.org/10.1111/j.1468-0297.2004.00216.x 
Lee, J. D.; Wang, Y. H.; Lin, C. W.; Lin, H. H. 2013. Information value of patent litigation and industry competition in Taiwan, Technological and Economic Development of Economy 19(4): 593-605. http://dx.doi.org/10.3846/20294913.2013.837109

Lerner, J. 1994. The importance of patent scope: an empirical analysis, RAND Journal of Economics 25(2): 319-333. http://dx.doi.org/10.2307/2555833

Lev, B. 2001. Intangibles: management, measurement, and reporting. Washington DC: Bookings Institution Press.

Li, F.; Whalley, J. 2002. Deconstruction of the telecommunications industry: from value chains to value networks, Telecommunications Policy 26(9-10): 451-472. http://dx.doi.org/10.1016/S0308-5961(02)00056-3

McAleer, M.; Hoti, S.; Chan, F. 2009. Structure and asymptotic theory for multivariate asymmetric conditional volatility, Econometric Reviews 28(5): 422-440. http://dx.doi.org/10.1080/07474930802467217

Megna, P.; Klock, M. 1993. The impact of intangible capital on Tobin's Q in the semiconductor industry, American Economic Review 83: 265-269.

Narin, F.; Noma, E.; Perry, R. 1987. Patents as indicators of corporate technological strength, Research Policy 16(3): 143-155. http://dx.doi.org/10.1016/0048-7333(87)90028-X

Nelson, D. 1991. Conditional heteroskedasticity in asset returns: a new approach, Econometria 59: 347-370. http://dx.doi.org/10.2307/2938260

Oughton, C.; Landabaso, M.; Morgan, K. 2002. The regional innovation paradox: innovation policy and industrial policy, Journal of Technology Transfer 27(1): 97-110. http://dx.doi.org/10.1023/A:1013104805703

Porter, M. E. 1980. Competitive strategy: techniques for analyzing industries and competitors. New York: Free press.

Porter, M. E. 2008. The five competitive forces that shape strategy, Harvard Business Review 86(1): 78-93.

Raghu, T. S.; Woo, W.; Mohan, S. B.; Rao, H. R. 2008. Market reaction to patent infringement litigations in the information technology industry, Information Systems Frontiers 10(1): 61-75. http://dx.doi.org/10.1007/s10796-007-9036-5

Reitzig, M. 2003. What determines patent value- insights from the semiconductor industry, Research Policy 32(1): 13-26. http://dx.doi.org/10.1016/S0048-7333(01)00193-7

Schoenecker, T.; Swanson, L. 2002. Indicators of firm technological capability: validity and performance implications, IEEE Transactions on Engineering Management 49(1): 36-44. http://dx.doi.org/10.1109/17.985746

Suzuki, J. 2011. Structural modeling of the value of patent, Research Policy 40: 986-1000. http://dx.doi.org/10.1016/j.respol.2011.05.006

Thomas, P. 2001. A relationship between technology indicators and stock market performance, Scientometrics 51(1): 319-333. http://dx.doi.org/10.1023/A:1010597502646

Trajtenberg, M. 1990. A penny for your quotes: patent citations and the value of innovation, RAND Journal of Economics 21(1): 172-187. http://dx.doi.org/10.2307/2555502

Trajtenberg, M. 2001. Innovation in Israel 1968-1997: a comparative analysis using patent data, Research Policy 30(3): 363-389. http://dx.doi.org/10.1016/S0048-7333(00)00089-5

Trippl, M.; Maier, G. 2010. Knowledge spillover agents and regional development, Papers in Regional Science 89(2): 229-233. http://dx.doi.org/10.1111/j.1435-5957.2010.00302.x

Tsai, M.; Su, K. H.; Chen, M. J. 2011. Seeing through the eyes of a rival: competitor acumen based on rival-centric perceptions, Academy of Management Journal 54(4): 761-778. http://dx.doi.org/10.5465/AMJ.2011.64870138 
Tseng, C. Y.; Wu, L. Y. 2007. Innovation quality in the automobile industry: measurement indicators and performance implications, International Journal of Technology Management 37(1-2): 162-177. http://dx.doi.org/10.1504/IJTM.2007.011809

Wang, P.; Moore, T. 2008. Stock market integration for the transition economies: time-varying conditional correlation approach, The Manchester School 76(S1): 116-133. http://dx.doi.org/10.1111/j.1467-9957.2008.01083.x

Watanabe, C.; Tsuji, Y. S.; Griffy-Brown, C. 2001. Patent statistics: deciphering a 'real' versus a 'pseudo' proxy of innovation, Technovation 21(12): 783-790.

http://dx.doi.org/10.1016/S0166-4972(01)00025-6

Yi-Hsien WANG. Doctor, Professor at the Department of Banking and Finance, Chinese Culture University in Taiwan, and holds $\mathrm{PhD}$ in the Graduate School of Management, Ming Chuan University in Taiwan. His current research interests are in the area of financial management, decision science and industry competitive analysis.

Wan-Rung LIN. Doctor, Associate Professor at the Department of Banking and Finance, Chinese Culture University in Taiwan. She received a Doctoral Degree from National Central University. Her current research interests are in the area of financial management, mobile banking, multiple criteria decision making, and wealth management. Her recent publications have appeared in the Journal of Grey System, Journal of Information and Optimization Sciences, Empirical Economics Letters, International Journal of Hospitality Management, Energy, International Journal of Production Research, and Journal of Testing and Evaluation.

Shu-Shian LIN. Doctor, Associate Professor of Department of International Business Administration, Chinese Culture University, and holds PhD from the Graduate School of National Central University. His current researches focus on international relationship of stocks, momentum investment strategy and simulation of financial derivatives.

Jui-Cheng HUNG. Doctor, Associate Professor at the Department of Banking and Finance, Chinese Culture University. He gains Ph.D degree at Department of Banking and Finance, Tamkang University. His research area includes volatility forecast, financial risk management and market microstructure. His paper appeared in Journal of Futures Market, Journal of Empirical Finance, Energy Economics, Economic Modelling, Applied Economics and Applied Financial Economics. 